International Journal of Linguistics, Literature and Culture
Available online at https://sloap.org/journals/index.php/ijllc/
Vol. 7, No. 4, July 2021, pages: 201-208
ISSN: 2455-8028
https://doi.org/10.21744/ijllc.v7n4.1426

\title{
English and Uzbek Toponymic Phraseological Units: Linguocultural and Historical Aspects
}

Xudoyorova Safura Tulkin qizi ${ }^{\text {a }}$

Article history:

Submitted: 9 February 2021

Revised: 18 March 2021

Accepted: 27 April 2021

\section{Keywords:}

toponym;

onomastics;

phraseological unit;

geography;

history;

\begin{abstract}
The present paper is devoted to investigation of English and Uzbek phraseological units which contain place names in their structure. An attempt is made to find out the sources of origin as well as to analyze them from linguocultural point of view. Toponymic phraseological units in both languages are classified into five main groups according to the emergence sources and particular attention is given to the historically associated phraseological units. Here the phraseological units that are based on the exact historical events and facts are discovered and explained. The author proposes two major groups of phraseological units concerning the existence of real place names in their structure. There are also revealed properties of real toponyms that stimulated the connection in the meaning of a proper name and a phraseological unit. Additional connotation of toponyms which influenced on the meaning of phraseological units are also discovered. The examples are taken from several English and Uzbek phraseological and paremiological dictionaries. The examples are analyzed by descriptive and comparative methods. Similarities and differences are found out due to national-cultural specifics of both languages.
\end{abstract}

International journal of linguistics, literature and culture (C) 2021. This is an open access article under the CC BY-NC-ND license (https://creativecommons.org/licenses/by-nc-nd/4.0/).

Corresponding author:

Safura, T.X.

Samarkand State Institute of Foreign Languages, Samarkand, Uzbekistan

Email address: xudoyorovasafura@gmail.com

${ }^{a}$ Samarkand State Institute of Foreign Languages, Samarkand, Uzbekistan 


\section{Introduction}

Indeed, culture and language are inseparably linked as V.N. Teliya (1996) stresses "culture is a peculiar historical memory of a nation. And language, thanks to its cumulative function, preserves in it, ensuring the dialogue of generations not only from the past to the present but from the present to the future". Proper names are the most important source of information about the cultural, historical, sociolinguistic and geographical aspects of the life of native speakers. At the same time, phraseology is a vivid reflection of the uniqueness of people's way of life, history and traditions. Thus, phraseological units (PUs) with place names carry a vivid national, historical and cultural semantics since toponyms not only denote a place, but also preserve national and cultural information. Despite the abundance of research works on onomastic phraseology, PUs with place names are still the subject of interest even today in English and Uzbek phraseology. Complexity of use and comprehension of PUs containing place names makes the current study actual and important. Actual becomes also exploring the extralinguistic contributing factors of such units and analyzing cultural specifics in both languages.

General theory of proper names were thoroughly studied by A.A .Reformatskiy, A.V. Superanskaya , V.A. Nikonov, E.A. Begmatov, B. Bafoev and others. English phraseological units that feature proper names have repeatedly been the subject of consideration of linguists T. V. Likhovidova,V. G. R. Ganiyeva, G.P. Manushkina, O. Safronova, Z.V. Korzyukova V. Elenka , Ya. P Ignatovich. Uzek toponymy was discussed in the works of H. Hasanov, S.Q. Qorayev, Z. Do'simov, T. Nafasov and etc. Linguocultural aspects of Pus containing toponymic element have been studied in the works of a number of researchers, in particular, A.V. Urazmetova, V.A.Xoxlova, I.A. Kondakova ,C.A. Kalinina, E.N. Gilyazeva and others.

Proper name (onym) - (from the Greek. Onoma - name,) - a word, phrase or sentence that serves to distinguish the named object from a number of similar ones, individualizing and identifying this object (Superanskaya, 1973). According to Superanskaya (1973), proper names are a part of the language, demonstrating the most paradoxical situations, the analysis of which should contribute to the emergence of new, more profound general linguistic concepts. Proper nouns carry some information about this particular object, about its properties. This information can be rich or poor, and it is known to varying degrees in different spheres of communication. If this information is disseminated throughout the entire linguistic community, it means that information about this subject is part of the linguistic meaning of the proper name (Ermolovich, 2001; Dossymbekova et al., 2015). Actually, this linguistic meaning is pivotal in the occurrence of phraseological units with proper name component as the meaning of such Pus are predominantly based on the culture specific meaning of a proper name.

Toponymy is an integral part of onomastics that studies geographic names (place names), their meaning, structure, origin and distribution. A set of toponyms in any territory constitutes its toponymy (Nikonov, 2011). Traditionally, the toponym is understood as the proper name of any geographical object, any object on the surface of the earth or in its deep interior, distinguished by man as an independent unit (Superanskaya, 1984), Davletkulova (2014) defines toponyms as "historically, socially and culturally determined geographical names of any natural or artificial objects created by man on the land or water territory of the earth. Geographical names are very stable, persist for a long time, becoming a kind of historical monuments, therefore toponymy, according to the opinion of many researchers, also belongs to a certain extent to history and source studies (Nikonov, 2011; Garaeva, 2014). The status of a toponym is determined by its main functions in the linguistic culture of an ethnic group: a) nominative (naming); b) individualizing (identification); c) cumulative; d) culture-bearing (Sedykh et al., 2020). Nikonov (2011) in his work "Introduction to place names" distinguishes three meaning plans of toponyms: pretoponymic, proper toponymic and post-toponymic. 1) Pre-toponymic (appellative, etymological) meaning is the meaning of the word from which the toponym was formed (in most cases this meaning can only be traced back by special etymologycal analysis) 2) proper toponymic (direct geographic) meaning refers to the functioning of place names in speech (it has nothing general with the first, since it lies on another plan) 3) ottoponymic (post-toponymic) meaning - these are associations connecting people to the naming as a result of familiarity with an object. It is vitally important to know the post - toponymic meaning as the meaning of Pus with toponymic element are based on it.

Maslova (2005) emphasizes the role of background knowledge in realizing the PUs with proper name constituents, stating that the denotative aspect plays an important part in the meaning of phraseological units containing proper nouns. The history of people is reflected in these phraseological units; therefore, to understand them, one must know specific historical facts. In all languages of the world, many phraseological units are based on the names of cities, streets, rivers, oceans as well as on the realities associated with toponyms. PUs with toponymic component reflect centuries old human observations of the world of toponymy, convey the attitude of people to this area of reality (Gilyazeva\&Bazarova, 2018; Nefedova, 2014). 


\section{Materials and Methods}

The relevant data for the study were mainly sourced from English and Uzbek phraseological and paremiological dictionaries. It is essential to know the motivation of PUs in order to use them more consciously. In this study, linguistic and exralinguistic factors which influenced on the toponymic PUs are discussed. 454 English and 59 Uzbek PUs with toponymic elements were gathered and shining units were taken as examples. They are examined based on descriptive, comparative and etymological methods. Historical, cultural and geographical associations of such units were mainly focused on.

\section{Results and Discussions}

\subsection{Classification of PUs regarding the sources of origin}

There are many place names that were formed as part of PUs. It is essential to explore how and when they appeared and deciding factors of their emergence. In some cases, these PUs experience semantic transformations as time passes. Therefore, in the investigation of such PUs, motivation and etymology of toponymic constituents play vital role. In the process of investigation there were found the following groups of PUs regarding the sources of origin:

\section{PUs which originated under the influence of certain socio-historical factors, events and facts}

Shipshape and Bristol fashion - to be perfectly in order (in the middle of $19^{\text {th }}$ century Bristol was a famous as a port city in England. The expression emphasized the commercial prosperity of Bristol Port and its good shipping conditions) (Shitova, 2012; Rezanova \& Khlebnikova, 2015) cross the Rubicon - take an irrevocable action (The Rubicon was a small river in north east Italy. By taking his army across the Rubicon into Italy in 49 BC, Julius Caesar broke the law forbidding a general to lead an army out of his own province, and so commited himself to war against the Senate and Pompey (Judith, 2004). In uzbek: gap quvgan baloga yo'liqar, yo'l quvgan G'aznaga - the expression refers to the fact that G'azna was one of the cultural, political and trade center of central Asia in the middle ages. In most cases the meaning of such units closely associated with the origin of PUs. Thus, PUs with onomastic components are essential source of information about history, culture and traditions of an ethnos (Xudoyorova, 2020; Shoikova \& Tikhonova, 2014).

\section{PUs that emerged from literary sources}

The name of the places in folk art and fiction where certain events happened enriched the phraseological fund of the both languages: green like a Cheshire cat - to smile broadly (the expression gained particular popularity after the use in Lewis Carrol's Alice's Adventures in Wonderland (1865) (Shitova, 2012; Yushkova \& Neborskaya, 2015); wise man of Gotham - a person who seems fool at first glance but actually on his mind (Gotham is a hamlet in Nottinghamshire, England. It was a place of national story "Sages of Gotham"); Bir aqlsizga aql bergandan Qof tog'ini egov bilan un qilgan oson - making someone sensible is nearly unattainable task (Ko'hi Qof is a legendary mountain which was used in A. Firdavsiy's Shohnoma).

\section{PUs with toponyms which are taken from the Holy books and mythological place names}

This group includes antic, biblical, greek mythological place names and koranic toponyms: a perfect Babel confusion caused by language, a complete discord (it is connected with the biblical story about how people dispersed in the world); corn in Egypt - abundance of smth ; Soddom and Gomorrah - chaos (from the names of two cities in the Bible); pile/heap Pelion on Ossa - to complicate an already difficult task (in greek mythology, Mount Pelion was a dwelling of centaurs); In uzbek language there are severel PUs with Mecca, the holiest city in Islam, the place of pilgrimage (Hajj) in Saudi Arabia: bir ko'ngil imorati ming Makka ziyorati - making someone happy is equal to make a pilgrimage to Mecca thousand times; Hoji hojini makkada ko'radi - it is used when relatives or neighbours meet by accident in another city or place; eshak Makkaga borgani bilan halol bo'lmaydi - a stupid person never changes (Mirzayev et al., 1989). It is interesting to note that in English there is a PU with Mecca although English

Xudoyorova, S. (2021). English and uzbek toponymic phraseological units: Linguocultural and historical aspects. International Journal of Linguistics, Literature and Culture, 7(4), 201-208. https://doi.org/10.21744/ijllc.v7n4.1426 
and Uzbek are genetically unrelated languages: a Mecca - a place that is important to a certain group of people and often visited by them.

PUs connected customs, traditions and everyday life

Be full of / Talk Blarney - give inconceivable promises, flatter and deceive. The Blarney Stone is a stone with the same name in Ireland. According to tradition, by kissing this stone a person acquires the ability to charm and convince people (Shitova, 2012). In the Uzbek language PUs with toponymic components which are related to customs and everyday life: Beva xotinga Buxorodan it huradi - it is difficult for a widow to live alone as people may gossip about her; Eshonbozorda it o'lsa "yigirma" sidan quruq qolmaydi - a person who visits everywhere especially to ceremonies (Eshonbozor is a village in southern Kazakhstan, yigirma is a religious ceremony which is held after death); ahmoqqa Quva bir tosh - it is used when a person who does smth incompletely and has to do it again;

\section{PUs that came from other languages: phraseological calques and borrowings}

It is almost impossible to find the exact synonyms of such units in other languages, thus toponymic Pus in most cases are borrowed: In English discover America also exist in Uzbek, Amerika ochmoq - to say or state something that is already discovered; There are phraseological calques which exist in both languages but in some cases they differentiate in meaning, for instance, Chinese wall means barrier in English as there have never been unique plan of its construction and in uzbek Xitoy devori means something stable and durable. Different feautures of the same phenomenon were taken into account in the two languages. It should be stressed that they are connected to the historical events and phenomena that are worldwide known.

\subsection{Deeper insight into historically associated PUs}

Phraseological units with toponymic element are great insight into countries past. The metaphorical transfer underlying the meaning of phraseological units, including individual toponyms, can be based on real-life situations (Kuchesheva, 2008). According to E.V. Ivantsova (1996) there are two groups of phraseological units by the type of phraseologization: 1) phraseological units with proper nouns reinterpreted within the phraseological unit; 2) phraseological units containing proper nouns that had gone through semantic transformation before the phraseological unit was formed, and the phraseologization occurred not based on the denotative correlation of meanings of proper nouns but based on the symbolic meanings it had before. Discussing the linguacultural peculiarities of toponymic PUs, Khokhlova (2017) maintains that it is essential to single out a culturally significant component and subject it to a multifaceted analysis. In toponymic phraseology, such is the toponym component, which, as part of the phraseological unit, "undergoes qualitative changes and acquires new meanings, thereby enhancing the national flavor of phraseological units"

In English, historically associated toponymic Pus are related to certain historical facts and linked to both national and world history: Kentishman, man of Kent - although both people were born in the county Kent, Kentishman was born in the west of Medway river, while man of Kent to the south of it. The historical origin of the difference is due to the fact that the inhabitants of the eastern part of the county defended their homeland from William, the Conqueror in 1066; meet one's Waterloo - to be defeated (the Emperor Napoleon I was finally defeated in the Battle of Waterloo in 1815). Some of such units have more than one version of origin since the events of the distant past caused the emergence of such units: Send someone to Coventry - refuse to associate with or speak to someone. The expression, which dates from the mid- $18^{\text {th }}$ century, is thought by some to stem from the extreme unpopularity of soldiers stationed in Coventry, who were cut off socially by citizens. Another suggestion is that the phrase arose because Royalist prisoners were sent to Coventry during the English Civil War, the city being staunchly Parliamentarian (Judith, 2004). It should be stressed that most of such units appeared related to social, political and judicial processes in different stages of national and world history (Xudoyorova, 2020, p.107): Queensberry rules fair play (generally accepted rules of boxing, the code of practice was initiated by the $9^{\text {th }}$ Marquis of Queensberry and published in 1867). The Vietnam syndrome - the position of US government that diplomacy can be more effective solving domestic issues of other countries than use of military force (demonstrated by the failure of the American intervention in Vietnam). In English, certain events happened in particular places had lasting impression on people and most PUs connected with the place name affected on the meaning of phraseologisms. Having been 
known for its gallows, Tyburn was a main execution cite in London from $16^{\text {th }}$ to $18^{\text {th }}$ century and most of the PUs associated with this manor are connected to its former function: Tyburn dance - hanging; king of Tyburn - hangman, executioner; Tyburn tree - gallows.

Although history related toponymic PUs in Uzbek are not linked directly to particular past events, they allude to the life experiences and socio-economic situations in the past: Turkistonda qo'y bir so'm, kela-kela o'n bir so'm the phrase implies that Turkiston was a trade center and goods became more and more expensive when they were brought; so'rab-so'rab Makkani topibdi - it is possible to do everything if a person desires (in the past, Islamic people used to make a pilgrimage to Mecca on foot)[149 abd]; it is also noteworthy that toponymic PUs with historical content are expressed by word play and alliteration in uzbek: Ovozasi olamga ketgan, Dong' $i$ Dog'istondan o'tgan - internationally famous; tokni qirqmasang, Qashqarga yetadi - incitement may cause serious consequences if not hindered. Qashqar is a city in the western part of China. In the past, being situated at the intersection of the Great Silk road it was trade center.

It is essential to know the motivation of such units to realize their meaning. Considering the motivation of phraseological units with proper name T.V. Likhovidova (1971) rightly notes that diachronically all phraseological units with proper names are etymologically motivated, since at the moment of their emergence, native speakers distinctly realized the connection between a proper name and the meaning of phraseological unit, while most of them lost their motivation in the synchronous plan. In English the phraseologism The sick man of Europe referred to Turkey as King Nikolay I called the country in 1853, now any European country which is in difficult economic situation (Kunin, 1984).

\section{Archaic place names in PUs}

In the English and Uzbek languages toponymic PUs that have archaic place names in their structure tend to become archaic phraseologisms as time goes by: perfidicious Albion - the nickname of England (Albion was an ancient name of The Great Britain) (Kunin, 1984). Gap desang qop-qop, ish desang Ashtarxondan top - a person who is boastful and extremely lazy (Ashtarxon was one of the khanates in $15^{\text {th }}$ century in Central Asia). Archaisms complicates the use and understanding processes even for native speakers. As can be observed, just knowing the name and geographical position of a place is not sufficient to realize the meaning of these unit as particular historical events, socio-economic and political situations linked to the toponym in the structure of PUs reflect in their semantics. All of such units in both languages are used metaphorically.

\subsection{Real or fabulous place names in PUs}

Two major groups of PUs were revealed in the both languages regarding the existence of the toponyms in reality:

\section{PUs coantaining real place names}

In the structure of phraseologisms, we can observe the names of places which exist or existed in the past. The meaning of each phraseologism is based on the particular feature of a toponym or associations linked to the toponym. In Pus with toponyms which existed or still exist in real life several peculiarities of the toponyms become dominant:

\section{Geographical properties}

London particular - dense fog; in uzbek: Mirzai azimda ming Xorunning xazinasi-yu, tuman Jamshidning davlati bor - this phrase emphasizes the fertileness of the desert Mirza (Mirzacho'l is a name of the desert between Syrdarya and Djizzak regions in Uzbekistan); Damachining qovunini yemabsiz - dunyoga kelmabsiz - it is used when you highly praise the quality of smth, (Damachi is a village in Zangiota, near Tashkent).

\section{Economic and manufacturing opportunities}

Windsor chair - carved wooden chair (The first batch of chairs was made in Windsor city and brought to London for sale in 1724); in most cases certain place names are famous for its product and this makes the unit more expressive and comprehensible: carry coals to Newcastle - to do something that is fruitless or bring something where there is in abundance (Newcasle is a city in Enland in the vicinity of where there are many coal mines); not for all the coffee in

Xudoyorova, S. (2021). English and uzbek toponymic phraseological units: Linguocultural and historical aspects. International Journal of Linguistics, Literature and Culture, 7(4), 201-208. https://doi.org/10.21744/ijllc.v7n4.1426 
Brazil/ not for all the tea in China - not for the world ; yeyishing-sholg'omu, kiyishing-Marg'ilonning sirli saroyiit is used when a person spends much money on clothing even though he has nothing to eat (Margilon is a city in Fergana district which has been famous for its atlas (atlas is a type of uzbek national cloth) (Shomaqsudov, \& Shorahmedov, 1987).

\section{General characteristic trait of inhabitants:}

In some units, stereotypical attitudes towards the population of particular places, their common characteristics symbolize the whole place: from Missouri - a distrustful person (Missouri is a state in the central part of the United States, unofficial name - the "Show-me State"); Attic salt - subtle wit (the ancient greek region Attica was famous for the wit of its inhabitants; yonida bir puli yo' $q$ G'irvonga hokim - a person who desires something completely impossible (G'irvon is a village near Namangan city and its dwellers had a reputation of being naive).

\section{Distance between toponyms:}

Geographical position of places, especially faraway ones are reflected in PUs: from China to Peru - everywhere; from here to Timbuktu - distant countries; in Uzbek dunyoning narigi chekkasi/ dunyoning u burchagi means the same but, they do not contain toponyms.

\section{PUs with imaginary place names}

Utopian dreams - beautiful but impractical plans. Utopia is a blessed country with an ideal socio-political and legal system. Thomas More describes a fantastic island in the Atlantic Ocean in his book "Utopia" (1516); The Elysian fields - heaven. Homer describes the Elysian Fields as the happy land in which the blessed spirits live in the afterlife; the land of Cockaigne - dreamland of abundance and idleness, paradise on earth (Kunin, 1984); Qasd qilgan - Qof tog'idan o'tar, Hasad qilgan - o'z oyog'idan yitar - if you admire, you will achieve your goals while feeling envious causes failure (Qof is a legendary mountain which is ardous to reach); amri padar - Arshdan a'lo - it is highly advisable for children to obey father's orders (according to religious attitudes, Arsh is a place in the sky, near god). The great majority of such units describe the ideal and perfect places where people admire to live in.

\section{Conclusion}

The article can be concluded with a few observations:

1) PUs containing place names in their structure have social, geographical and historical associations that are part of background and communicative knowledge of native speakers. Facts and events from the distant past, religion, literature, customs and traditions of a nation stimulated the formation of PUs with place name element. They feature culturally marked and historically associated information as a wide range of extralinguistic factors contributed to their origin. Therefore, national-cultural component of a toponym plays significant part in the semantics of such units.

2) Although most of the analyzed groups of PUs have alike features, functions and originated from similar sources in both languages, it is nearly impossible to find exact parallels except international PUs (biblical, mythologic) in other languages since they are related to unique national-cultural concepts and realias of each nation.

3) In the PUs with real place names distinctive features of the place names becomes dominant and PUs with fictional toponyms demonstrate fabulous places where people's dreams come true. This reveals geographical properties and national psychology of a country.

4) Motivation and etymology of history related PUs are of great importance since they are linked to particular events, facts and socio-political situations. Hence, they need specific interpretation in phraseological dictionaries.

5) Place names have various meanings and connotations due to culture specific associations. Symbolic and stereotypical meanings of place names that were formed for long periods of time affect the overall connotation of a unit. Thus, in toponymic phraseologims, whether the unit is positively or negatively marked heavily depends on the place name in the structure of a phraseological unit. 
Conflict of interest statement

The author declared that (s)he has no competing interest.

Statement of authorship

The author has a responsibility for the conception and design of the study. The author has approved the final article.

Acknowledgments

I am grateful to two anonymous reviewers for their valuable comments on the earlier version of this paper.

Xudoyorova, S. (2021). English and uzbek toponymic phraseological units: Linguocultural and historical aspects. International Journal of Linguistics, Literature and Culture, 7(4), 201-208. https://doi.org/10.21744/ijllc.v7n4.1426 


\section{References}

Davletkulova, L.N., (2014) Toponyms in linguacturological aspect (on the examples of geographical names in Oxfordshire and Chelyabinsk regions). Diss....Cand.,philologist.sciences.- Chelyabinsk.

Dossymbekova, R., Daulet, F., Kenzhebaeva, A., \& Zeinolla, Z. (2015). Linguocultural Aspects of Numerology in the Kazakh and Chinese Languages. Procedia-Social and Behavioral Sciences, 197, 2512-2519. https://doi.org/10.1016/j.sbspro.2015.07.325

Ermolovich, D. I. (2001). Proper names in different languages and cultures.

Garaeva, A. (2014). The development of linguocultural competence of students in teaching the history of the English language. Procedia-Social and Behavioral $\quad$ Sciences, 152, 1012-1018. https://doi.org/10.1016/j.sbspro.2014.09.359

Gilyazeva, E. N., \& Bazarova, L. (2018). The sources of origin and motivation of phraseological units with anthroponymic component in the German and Russian languages. Modern Journal of Language Teaching Methods, 8(11), 223-227.

Ivantsova, E.V., (1996) Semantic transformation of proper names in lexicology and phraseology of modern Russian language Reports from the 5th International Conference. . M.: MGOPU. Vol. 1

Judith, S. (2004). The Oxford Dictionary of Idioms. $2^{\text {nd }}$ ed. Oxford University press

Kalmuratov, B. S. (2020). The current state of innovative development of the construction industry of the Republic of Uzbekistan. ISJ Theoretical \& Applied Science, 2(82), 455-463.

Kohklova, V.A., (2017) Phraseological units with toponymic component in the English and Ukrainian languages: linguoculturological aspect: Diss. ... cand. of philol.sciences. - Donetsk.

Kuchesheva, I. L. (2008) Lexico-semantic analysis of proper names in compostion of English and Russian phraseological units: linguistic-cultural approach // Vestnik ChitGU, 3(48). - p. 30-33 UDC 802.0

Kunin, A.V., (1984) English-Russian phraseological dictionary. - Moscow: Russian language.

Likhovidova, T.V., (1971) Phraseological units with proper names in modern English/ T.V. Likhovidova IYASH. 6

Maslova, V. A. (2004). Cognitive linguistics. Minsk: TetraSystems.

Mirzayev, T. (1989) Uzbek national proverbs. - T. Literature and art publishing.

Nefedova, L. A. (2014). On the Use of Interphraseologisms in the Journalistic Discourse of German and Russian Linguocultures. Procedia-Social and Behavioral 130-137. https://doi.org/10.1016/j.sbspro.2014.10.124

Nikonov, V.A., (2011) Introduction to Toponymy. Pub. $2^{\text {nd }}$ ed. - M.: Publishing LKI.

Rezanova, Z. I., \& Khlebnikova, A. L. (2015). Gender metaphors in Russian and English linguocultures: a comparative study. Procedia-Social and Behavioral Sciences, 215, 273-278. https://doi.org/10.1016/j.sbspro.2015.11.634

Sedykh, A., Marabini, A., Stryzhnova, M., Bolgova, E., \& Bolgova, N. (2020). Toponymic phraseological unit, linguistic thinking and discourse: Russia, France and Italy. Revista Inclusiones, 488-500.

Shitova, L.F. (20120) Carry Coals to Newcastle. 350 Geographic idioms and more. SPb. Anthropology.

Shoikova, A. M., \& Tikhonova, E. V. (2014). The development of students' mental lexicon in legal discourse by means of authentic materials. Procedia-Social and Behavioral Sciences, 154, 522-526. https://doi.org/10.1016/j.sbspro.2014.10.179

Shomaqsudov, Sh., \& Shorahmedov, Sh., (1987) Why do we say so. Dictionary of Uzbek national proverbs. Tashkent.

Superanskaya, A.V., (1973) Genaral theory of proper nouns. Moscow: Nauka.1973.

Superanskaya, A.V., What is toponymy? Moscow: Nauka. 1984

Teliya, V.N., (1996) Russian phraseology. Semantic, pragmatic and lingual-cultural aspects. Moscow: Nauka.

To'lqinovna, X. S. (2020). Archaic And Historical Elements In English And Uzbek Phraseological Units. The American Journal of Social Science and Education Innovations, 2(07), 104-111.

Yushkova, L., \& Neborskaya, V. (2015). Description of Linguocultural Concept of "Education" in German and Russian Linguistic Consciousness. Procedia-Social and Behavioral Sciences, 214, 1174-1180. https://doi.org/10.1016/j.sbspro.2015.11.738 